\title{
Assessing the Online Shopping Behaviour of Nigerian Youths
}

\author{
${ }^{1}$ Chris-Nnamchi J. N, ${ }^{2}$ Ifediora C. U., ${ }^{3}$ Nwanmuoh, Emmanuel Sunday, ${ }^{4}$ Eneh N. C. J. \\ ${ }^{123}$ Department of Marketing, University of Nigeria, Enugu Campus. \\ ${ }^{4}$ Department of Business Management, University of Nigeria, Enugu Campus.
}

\begin{abstract}
Background: Online shopping is the juice of buying and selling of products and services mostly adopted by the youths do their ability and zeal to always go online surfing and browsing as they look for solutions to their everyday needs.

Purpose: The objectives of this study were: to ascertain the extent to which youths carry out online shopping; to assess the level of satisfaction of youths towards shopping online; to determine the extent to which online shopping is preferred to traditional shopping; to find out the effect the fear of losing money while shopping online has on the shopping behaviour of youths; and to determine the effects fear of non-delivery of order has on online shopping.

Method: The population of the study is made up of students from three higher institutions in Enugu state. Convenience sampling technique was used in interviewing and administering the questionnaire to 90 respondentsafterwhichchi-square, and linear regression were used to test the hypotheses.

Result: The findings indicate that Nigerian youths shop online frequently whenever they access various sampling brands, price and delivery options same time. Also, online shopping is preferred to traditional shopping by the sampled youths because it is convenient, offer discounts, have objective reviews from other shoppers.

Conclusion: The online presence of most companies has created an opportunity for marketing firms to reach out to the youths by way of interacting with them and getting feedback on the companies products and services. Making it easy for the companies to know the best ways to improve their products or services. This study equally recommends that firms should focus more on establishing an online presence to attend to the shopping needs of youths in Nigeria.
\end{abstract}

Keywords: Online, marketing, shopping, youths, internet.

\section{INTRODUCTION}

In the business-to-consumer (B2C) e-commerce cycle activity, consumers use the internet for many reasons and purposes like searching for product features, prices or reviews, selecting products and services through the internet. Also, placing the order, making payments, or any other means which is then followed by delivering of the required products through the internet or other means and sales service through the internet or other means (Simha, 2010;Abiodun, 2015).

In the past decades, the internet has developed into a vast global marketplace for the exchange of products and services. In many developed countries, the internet has been adopted as an important medium, offering a wide assortment of products with24-hour availability and wide area coverage (Javadi, Dolatabadi, Nourbakhish, Poursaeedi, and Asadoolam, 2012). According to an e-marketer, as reported by Anthony (2015), while e-market across the rest of the world is growing at a rate of $16.8 \%$, African's e-market space is growing at a rate of $23.8 \%$ making it the fastest growing in the world.

In 2014, Nigeria record over $\$ 2$ million value of online transaction per week and close to $\$ 1.3$ billion monthly. Nigeria's e-commerce market is developing rapidly with an estimated growth rate of $2.5 \%$ annually (Anthony, 2015). As more Nigerian's patronise online retail platform following the Central Bank of Nigeria (CBN) cash-lite agenda and the Federal Government of Nigeria's National Broadband Policy 2013-2018, the Nigeria electronic commerce (e-commerce) sector is expected to increase further to as much as $\$ 13$ billion (NGN2.5 trillion) in value (Abiodun, 2015). According to the National Broadband Policy(NBP) 2013-2018, 80\% of the Nigerian's population is projected to enjoy mobile broadband access and 20\% fixed line access. The CBN's cashless policy commenced 
nationwide on July 1,2014, but beforethe beginningof the policy, in 2012, the sector recorded 1,000 ordersdaily, with market size standing at $\$ 35$ million (5.6 billion).

Today, the leading online stores achieve about $\$ 2$ million worth of transaction per week (approximately NGN1.5 billion per month). These figures further increased to 15,000 orders per day, with market size valued at $\$ 550$ million (NGN88 billion), (Abiodun, 2015). The growth in the e-commerce space in Nigeria has also been made possible by the activities of major online retailing platforms such as Konga.com, Jumia.com, DeelDey, QuikTeller, Wakanow, RyteDeals, Checki.com, among others.

Online shopping behaviouristhe process of purchasing products or services through the internet. The process consists of five stages similar to those associated with traditional shopping process. When potential consumer recognises a need for some merchandise or service,they go to the internet and search for need related information. However, rather than searching activity, at times potential consumers are attracted by the knowledge of products or services linked with the felt need. They then assess alternatives and choose the one that fits their criteria the most for meeting the felt need. Lastly, a transaction is conducted and post-sales services provided to the consumers. Online shopping attitude refers to the consumer's psychological state regarding making purchases on the internet (Lia and Zhary, 2002; Javadiet al., 2012).

\section{STATEMENT OF THE PROBLEM}

Online Marketing is the best increasing form of direct marketing. Recent technology advances have erected a digital age. Widespread use of the internet has dramatic importance on both buyers and the marketers who serve them. Much of the world's trade today is carried out over digital networks that join people and companies. The internet, vast mobileweb of computer networks connects users of all types all around the world to each other and an astonishingly large information storehouse.

Online shopping in Africa has blossomed recently, riding on the back of improved broadband access. Nigeria, Africa's largest economy is a leader in e-commerce growth, with 65 percent of the 50 million internet users in the country having at one time or the other shopped online. Those who have not shopped online making up 24 percent of the country total internet users expect to do so in the future (Aderibigbe, 2015). The internet has fundamentally changed customer's notions of convenience, speed, price, product information, and as a result, it has given marketers a whole new way to create value for the customer and build a relationship with them.

The modern day youths use online and social media in the day to day life. Millions of youths in Nigeria use the internet to search for information relating to products, price etc. The growing presence of youths, online, has translated into a series of online marketing companies' and retailers. Most youths go online in search and purchase of digital goods, footwear, physical entertainment such as books and CDs, consumer electronics such as mobile phones and accessories, jewellery and watches etc. This pertinent to above, the study sought to find out the factors that influence youths to get involved with shopping online.

\section{OBJECTIVES OF THE STUDY}

The main objective of this study is to find out that factors that influence youths to shop online. The specific objectives include:

1. To ascertain the extent to which youths carryout online shopping.

2. To access the level of satisfaction of youths towards shopping online.

3. To determine the extent to which online shopping is preferred to traditional shopping.

4. To find out the effect of losing money while shopping online; and

5. To determine the effects of fear on non-delivery of order on online shopping.

\section{RESEARCH QUESTIONS}

The study will focus on answer the following research question:

1. To what extent do youths in Nigeria carryout online shopping?

2. What is the level of satisfaction derived from youths from shopping online?

3. Is online shopping preferred to traditional shopping?

4. What is the effect of the risk of loss of money and financial details while shopping online? 
5. What is the effect of fear on the delivery of order on online shopping?

\section{RESEARCH HYPOTHESES}

The following Null hypotheses will be tested in the research work:

1. Nigerian youths do not shop online frequently.

2. The level of satisfaction of Nigerian youths towards online shopping is very low.

3. Online shopping is not preferable to traditional shopping.

4. The effect of the loss of money and financial details does not affect online shopping.

5. The effect of fear of non-delivery of order does not affect shopping online by Nigeria youths.

\section{Conceptual Definitions}

There are diverse definitions of what online marketing is. Broadly speaking online marketing is the art and science of selling products and services over digital networks like cellular phone networks and the internet (Ward, 2015). It involves finding the rights online marketing mix of strategies that appeals to your target market which eventually translates into sales. More specially, online marketing refers to a set of powerful tools and methodologies used for promoting product and services through the internet (Janssen, 2015). Online marketing involves a broad range of marketing elements than old-fashioned business marketing due to the marketing mechanisms and extra channels available on the internet. It is also known as Internet Marketing, Web Marketing, Digital Marketing and Search Engine Marketing (SEM). It can deliver benefits such as; growth in potential; reduced expenses; elegant communication; better control; improved customer services; competitive advantage.

The broad online marketing spectrum varies in line with business requirements. Effective online marketingprogrammes leverage customer data and customer relationship management system as it connects organisations with qualified potential clienteles and takes business development to a higher level than traditional marketing/advertising (Jassen, 2015). Online marketing synergistically combined the internet's creative and technical tools, involving design, sales, development and advertising, while focusing on the following primary business models: e-commerce; lead-based; websites; affiliate marketing; load search. Ward (2015), stated the types of online marketing to include: e-commerce; online advertising, search engine marketing, e-mail marketing, social media marketing and article marketing.

\section{ONLINE MARKETING AND PURCHASE BEHAVIOUR}

Various researches have been conducted in the area of online marketing behaviour of consumers. Bellman, Lolise and Johnson (1999) examined the relationship between demographics, personal characteristics, and attitude toward online shopping. The study reveals that people who have a wider lifestyle are time constrained by online. According to Swaminathan, Leptowsba, White, and Roa (1999), the following are the factors that influence online marketing:

- vendor characteristics,

- security of transactions,

- content for privacy and

- customer characteristics.

In the same vein, Donthu and Garcia (1999), proposed that the following would influence online shopping behaviour:

- risk aversion,

- innovativeness,

- brand consciousness,

- price consciousness,

- importance of convenience,

- variety-seeking propensity,

- impulsiveness,

- attitude toward advertising, 
- attitude towards shopping, and

- attitude toward direct marketing.

They added that among the above-listed factors; that the following will influence online shopping behaviour

- age, income,

- importance of convenience,

- innovativeness,

- risk aversion,

- impulsiveness,

- variety-seeking propensity,

- attitude toward direct marketing and advertising.

Wang, Liu and Cheng (2008), found that consumers think it to be risky to make online payments. Consumers were also expecting an increased level of privacy in online shopping, their experience with the internet and computer skill was also found as a factor influencing consumer behaviour.

Chowdthing and Ahmed (2011) as reported in Sharma, Melita and Sharma (2014), conducted a study on factors affecting consumers participation in online shopping using four variables (ability, benevolence, integrity and trust). The study offers a useful insight into the significant role of trust in students for shopping online. The variables tested in the work of Yuliham, Islam and Dand (2011) included usefulness of internet shopping, ease of use, compatibilities, privacy, security, normative beliefs, self-efficiency, attitude and students buying intentions.

Karim (2013) documented that online vendors can assume their consumers for business security and avoid long delays in completing online orders and the hassle of returning goods forthe better online shopping experience.Morise (2013) found that online shoppers want what is called a "Seamless Omni channel experience" meaning one in which retailers allow them to combine online and bricks and mortar browsing shopping, ordering and returning. With the increasing sizes, more demand by youths and change in the behaviour of youths towards shopping has indicated a huge market available to the incumbents and existing performers (Sharma, Melita and Sharma, (2014). Therefore, the importance of this study is to discover various factors that influence Nigerian youths into carrying out online shopping.

\section{BENEFITS OF ONLINE MARKETING}

There are various benefits that consumers and marketers get by using online marketing. According to Chou (2015), benefits to consumers include:

- Convenient: Customers can shop 24-hours a day from anywhere without going physically to the retail store.

- Interactive and Immediate: Consumers can interact with the seller's site to find the information, products or services they desire, then order or download them on the spot.

Furthermore, Chou (2015) stated four ways to conduct online marketing to include:

1. Creating an electronic storefront: companies can buy space on a commercial online service, or it can open its website. These sites are designed to involve consumers in an interaction that will move them closer to a purchase or other marketing outline.

2. Placing Advertising Online: companies can place online advertising in three ways:

- Classified advertising in special sections of major commercial online services.

- Advertising in certain internet newsgroups set up for commercial purposes

- Buy online advertising met pop up while people are surfing the web. Such advertising includes banner advertising, pop-up windows, "tickers" (banners moving across the screen), and "roadblocks" (full-screen advertising that users must go through to get to other screens they wish to view). 
3. Participating in an internet forum, Newsgroup, or web communities-companies may participate in or sponsor internet forum, newsgroups and bulletin boards that appeal to special interest groups.

4. Use online e-mail or webcasting companies can send out customer's newsletters, promotion offers or special products based on customer buying histories webcasting or "push" programming delivers information of interest to consumer's desktops.

\section{CHALLENGES OF ONLINE MARKETING}

Since the internet boom of the late 1990s, web-based companies are opening up on a daily basis. What is more, new opportunities for growth emerge daily, expanding the capabilities and reach of the cyberspace (Devi and Anita, 2013). However, for all its benefits and advantages, online marketing faces some problems that are unique to the industry. According to the authors, they include:

1. Marketing integration: Most main sales effort employ several channels both online and offline. E.g. email, advertising, outboard call handling social networking, and so on. The difficulty with these is that they are often handled as separate parts of the work when they are supposed to serve a concrete and measurable goal as part of an integrated campaign. Coordinating all marketing efforts should, therefore, be a printing.

2. Security and Privacy: Most individualsdo not completely trust web companies and thus, are careful about offering information about themselves on the cyberspace. This is especially true when companies that collect data are exposed to spammers and scammers.It is imperative for online companies to adopt a sound policy and implement a fool-proof security measure to be able to address this insecurity issue. Encryption systems, in particular, are a tool that online companies should consider investing in essentially.

3. Impersonal service: business is operating online often use electronic methods of providing customer service, such as e-mailing and posting on the website to answer possible user questions. Thus may be perceived by customers as just too impersonal or uncaring.

4. Improving brand awareness: is predominantly a big challenge for companies that primarily use the internet to sell their products and service. This is because unlike traditional advertising in which the campaign's message can be reinforced and repeatedly introduced to consumers as the marketers' will online advertisement can be shut off by users; they are more averse to it too.

\section{METHODOLOGY}

The study adopted a survey method. The population of the study is made up of students from three higher institutions in Enugu metropolis. The source of data is primary and was collected through the use of a questionnaire and personal interview. Convenience sampling technique was used in interviewing and administering the questionnaire to the respondents. A total of 90 copies of the questionnairewas administered. The hypotheses wereanalysed and tested with chi-square and linear regression with the aid of the computer through the application of Statistical Package for Social Sciences (SPSS).

\section{DATA ANALYSIS AND DISCUSSIONS}

The data obtained from the field were presented and analysed with descriptive and inferential statistics to provide an answerto the research questions while the corresponding hypotheses were tested with Chi-square and Regression.

Table 1: frequency for the extent of online shopping by youths in Nigeria.

\begin{tabular}{|l|l|l|l|}
\hline & Observed N & Expected N & Residual \\
\hline More Frequently & 50 & 30.0 & 20.0 \\
Frequently & 30 & 30.0 & .0 \\
Occasionally & 10 & 30.0 & -20.0 \\
Total & 90 & & \\
\hline
\end{tabular}


Source: SPSS Result

Table 1contains a list of the number of cases (both observed and expected) in each category of the variable being analysed.

\section{Test of Hypotheses}

$\mathrm{HO}_{1}$ : Nigeria youths do not shop online frequently.

Table 2: Test statistics

\begin{tabular}{|l|l|l|l|}
\hline & Chi-square & df & Asymp. Sig. \\
\hline The extent of online shopping by youths in Nigeria. & 26.667 & 2 & .000 \\
\hline
\end{tabular}

Source: SPSS Result.

Table: 2 contains the output of the chi-square test. Small significance values (less 0.5) indicate that the observed distribution does not conform to the hypothesised distribution. From the table, the significance value of .000 is less than 0.05 . Therefore the stated hypothesis is not accepted. This shows that Nigerian youths shop online frequently.

Table 3: Frequency for the level of satisfaction youths derive from shopping online

\begin{tabular}{|l|l|l|l|}
\hline Highly satisfied & 40 & 30.0 & 10.0 \\
\hline Satisfied & 40 & 30.0 & 10.0 \\
Less satisfied & 10 & 30.0 & -20.0 \\
Total & 90 & & \\
\hline
\end{tabular}

Source: SPSS Result.

Table 3 shows the observed and expected cases in each of the categories of the variablebeing analysed. It includes the residual values of the variables too.

\section{$\mathrm{HO}_{2}$ : The level of satisfaction of Nigerian youths towards online shopping is very low.}

Table 4: Test Statistics.

\begin{tabular}{|l|l|l|l|}
\hline & Chi-square & Df & Asymp. Sig \\
\hline Level of satisfaction & 20.00 & 2 & .000 \\
\hline
\end{tabular}

Source: SPSS Result.

From table 4 , the significance value is .000 less than 0.5 which indicates that the observed distribution does not conform to the hypothesised distribution. Therefore, the hypothesis that the level of satisfaction of youths towards online shopping is very low is not accepted.

Table 5: Frequency of online shopping as preferred to traditional shopping.

\begin{tabular}{|l|l|l|l|}
\hline & Observed N & Expected N & Residual \\
\hline Yes & 60 & 30.0 & 30.0 \\
No & 20 & 30.0 & -10.0 \\
Indifferent & 10 & 30.0 & -10.0 \\
Total & 90 & & \\
\hline
\end{tabular}

Source: SPSS Result. 


\section{DOI: $10.51386 / 25815946 /$ ijsms-v4i3p110}

Volume: 4 Issue: 3

May to June 2021

www.ijsmsjournal.org

Table 5 above lists the number of cases (both observed value and expected value) in each category of the variable being analysed.

$\mathrm{HO}_{3}$ : Online shopping is not preferable to traditional shopping.

Table 6: Test Statistics

\begin{tabular}{|l|l|l|l|}
\hline & Chi-square & Df & Asymp \\
\hline Online shopping as preferred to traditional shopping & 46.667 & 2 & .000 \\
\hline
\end{tabular}

Source: SPSS Result.

From table 6 , the significance value is .000 less than 0.5 which indicates that the observed distribution does not conform to the hypothesised distribution. Therefore, the hypothesis that online shopping is not preferable to traditional shopping is not accepted.

Table 7: Coded responses on the risk of losing money and financial details online

\begin{tabular}{|c|c|c|c|c|c|c|c|c|c|c|c|c|}
\hline \multirow[t]{2}{*}{$\begin{array}{l}\text { Questionnaire } \\
\text { Items }\end{array}$} & \multicolumn{2}{|c|}{$\begin{array}{l}\text { Strongly } \\
\text { Agree (1) }\end{array}$} & \multicolumn{2}{|c|}{ Agree (2) } & \multicolumn{2}{|c|}{$\begin{array}{l}\text { No } \\
\text { Opinion(3) }\end{array}$} & \multicolumn{2}{|c|}{$\begin{array}{l}\text { Disagree } \\
(4)\end{array}$} & \multicolumn{2}{|c|}{$\begin{array}{l}\text { Strongly } \\
\text { Disagree (5) }\end{array}$} & \multicolumn{2}{|c|}{ Total } \\
\hline & & & & & & & & & & & Freq & \\
\hline $\begin{array}{l}\text { Risk of losing money } \\
\text { and financial details } \\
\text { affect online shopping } \\
\text { in Nigeria }\end{array}$ & 30 & 33.3 & 40 & 44.4 & 10 & 11.1 & 5 & 56 & 5 & 5.6 & 90 & 100 \\
\hline $\begin{array}{l}\text { Youths make an online } \\
\text { purchase when assured } \\
\text { of the safety of } \\
\text { financial details and } \\
\text { money }\end{array}$ & 40 & 44.4 & 30 & 33.3 & 10 & 11.1 & 3 & 5.6 & 5 & 5.6 & 90 & 100 \\
\hline Total & 70 & & \begin{tabular}{|l|}
70 \\
\end{tabular} & & 20 & & 10 & & 10 & & 180 & \\
\hline Average \% & & 38.85 & & 38.85 & & 11.1 & & 5.6 & & 5.6 & & \\
\hline
\end{tabular}

Source: SPSS Result.

According to table 7, based on the aggregate response, $70(38.85 \%)$ indicated strongly agree, $70(38.85 \%)$ indicated agree, $20(11.1 \%)$ were neutral, $10(5.6 \%)$ indicated disagree while $10(5.6 \%)$ indicated strongly disagree. This shows that safety of money and financial details influence online shopping by youths in Nigeria.

Ho$_{4}$ : The risk of losing money and financial details negatively affect attitude toward online shopping.

Table 8: Model Summary

\begin{tabular}{|l|l|l|l|l|}
\hline Model & R & R. Square & Adjusted R. Square & Std. error of the estimate \\
\hline 1 & 0.960 & .923 & .922 & .304 \\
\hline
\end{tabular}

Source: SPSS Result.

From the table above, the value of $\mathrm{R}(0.960)$ indicates stronger relationships and $\mathrm{R}$.Square value of 923 is also large, indicating the model fit the population very well.

Table 9: ANOVA

\begin{tabular}{|l|l|l|l|l|l|}
\hline Model & Sum of Squares & d.f & Mean Square & F & Sig. \\
\hline Regression & 96.611 & 1 & 96.611 & 1048.127 & .000 \\
\hline Residual & 8.111 & 88 & .092 & & \\
\hline Total & 104.722 & 89 & & & \\
\hline \hline
\end{tabular}


Source: SPSS Result.

A model with a large sum in comparison to the residual sum of square indicates that model accounts for most of the variation in the dependent variables. From the table above, it is evident as Model's sum of square (96.611) compared to residual's (8.111). The significant value of F statistics (.00) is smaller than (0.05), indicating that the independent variables explained the variation in the dependent variables.

Table 10: Coefficients

\begin{tabular}{|l|l|l|l|l|l|}
\hline Model & \multicolumn{2}{|l|}{ Unstandardized Coefficient } & $\begin{array}{l}\text { Standardized } \\
\text { Coefficient }\end{array}$ & & \\
\hline & B & Std. Error & Beta & & \\
\hline (Constant) & .271 & .064 & & 4.255 & 0.00 \\
\hline Safety of money & .918 & .028 & .960 & 32.375 & 0.00 \\
\hline
\end{tabular}

Source: SPSS Result.

In testing hypothesis four, the t-statistics and its significant value were used. From table 10, the coefficient is positive (t-value of 32.375) with significant value (0.00). The implication is that the risk of losing money and financial details affect online shopping behaviour of youths in Nigeria. Therefore, the null hypothesis is not accepted.

Table 11: Coded responses on fear of non-delivery of an order

\begin{tabular}{|c|c|c|c|c|c|c|c|c|c|c|c|c|}
\hline $\begin{array}{l}\text { Questionnaire } \\
\text { Items }\end{array}$ & \multicolumn{2}{|c|}{$\begin{array}{l}\text { Strongly } \\
\text { Agree (1) }\end{array}$} & \multicolumn{2}{|c|}{$\begin{array}{l}\text { Agree } \\
\text { (2) }\end{array}$} & \multicolumn{2}{|c|}{$\begin{array}{l}\text { No } \\
\text { Opinion (3) }\end{array}$} & \multicolumn{2}{|c|}{$\begin{array}{l}\text { Disagree } \\
\text { (4) }\end{array}$} & \multicolumn{2}{|c|}{$\begin{array}{l}\text { Strongly } \\
\text { Disagree (5) }\end{array}$} & \multicolumn{2}{|c|}{ Total } \\
\hline & Freq & $\%$ & Freq & $\%$ & Freq & $\%$ & Freq & $\%$ & Freq & $\%$ & Freq & $\%$ \\
\hline $\begin{array}{l}\text { Fear of non-delivery } \\
\text { of the order will } \\
\text { affect how youths } \\
\text { shop online. }\end{array}$ & 40 & 44.4 & 30 & 33.3 & 10 & 11.1 & 5 & 5.6 & 5 & 5.6 & 90 & 100 \\
\hline $\begin{array}{l}\text { Youths that shop } \\
\text { online prefer } \\
\text { making payments on } \\
\text { delivery }\end{array}$ & 30 & 33.3 & 40 & 44.4 & 10 & 11.1 & 5 & 5.6 & 5 & 5.6 & 90 & 100 \\
\hline Total & 70 & & 70 & & 20 & & 10 & & 10 & & 100 & \\
\hline Average & & 38.85 & & 38.85 & & 11.1 & & 5.6 & & 5.6 & & \\
\hline
\end{tabular}

Source: SPSS Result.

According to Table 11, based on the aggregate response, $70(38.85 \%)$ indicated strongly agree, $70(38.85 \%)$ indicated agree, $20(11.1)$ were neutral, $10(5.6 \%)$ indicated Disagree while $10(5.6 \%)$ indicated strongly disagree. This shows that fear on non-delivery of order affects how youths shop online and would prefer making payments on delivery.

$\mathrm{HO}_{5}$ : Fear of non-delivery of the orderdoes not affect attitude towards shopping online.

Table 12: Model Summary

\begin{tabular}{|l|l|l|l|l|}
\hline Model & R & R. Square & Adjusted R. Square & Std. error of the estimate \\
\hline 1 & 0.960 & .923 & .922 & .304 \\
\hline
\end{tabular}

Source: SPSS Result. 
From the table above, the value of R (960) indicates stronger relationships and R. square value of .922 is also large, indicating that the model fit the popular train very well.

Table 13: Coefficients

\begin{tabular}{|l|l|l|l|l|l|}
\hline Model & \multicolumn{2}{|l|}{ Unstandardized Coefficient } & Standardized Coefficient & & \\
\hline & $\mathrm{B}$ & Std. Error & Beta & F & Sig. \\
\hline (Constant) & .271 & .064 & & 4.255 & 0.00 \\
\hline Non-delivery of order & .918 & .028 & .960 & 32.375 & 0.00 \\
\hline
\end{tabular}

Source: SPSS Result.

In testing hypothesis five, the f-statistics and its significant value were used. From table 9 the coefficient is positive ( $\mathrm{t}$-value of 32.375) with a significant value of (0.00). The implication is that fear of non-delivery of order by the youths affects their attitude towards online shopping. Therefore, the null hypothesis is not accepted.

\section{SUMMARY OF FINDINGS}

The results based on the descriptive and inferential statistics revealed the following:

1. Youths in Nigeria shop online frequently as they have the opportunity of different sampling brands, price and delivery options same time.

2. Satisfaction of youths towards online shopping is high as youths receive discounts, sometimes free delivery, guarantee, warranty and the belief of buying original products.

3. Online shopping is preferred to traditional shopping by Nigerian youths because it is convenient, offer discounts, have objective reviews from other shoppers.

4. The risk of losing money and other financial details affects the attitudes of youths towards online shopping.

5. Fear of non-delivery of order influence online shopping attitude of youths in Nigeria as they prefer payment on delivery.

\section{CONCLUSION}

Recent technological advancements have created a digital age in Nigeria, and widespread of the internet is having a dramatic impact on both the youths and the marketing companies who serve them in Nigeria. Most companies now have an online presence to enable them to connect with people especially the youths because millions of them use the internet to search for information relating to products and services. This has created an opportunity for marketing firms to reach out to the youths.

Despite the recent trend of online marketing and shopping, the risk of losing money and other financial details exist. Fear of non-delivery of order also exists, as youths prefer making an online purchase where safety and security of new transactions are guaranteed and also where they can make payments on delivery and shop on a website that is friendly and easy to navigate.

\section{RECOMMENDATIONS}

Based on the findings, the following recommendation was made:

1. Youths shop online is frequently these days and firms should focus more on establishing an online presence to attend to the shopping needs of youths in Nigeria.

2. The level of satisfaction derived by youths while shopping online is encouraging, and firms should do more to ratify a few problems faced while shopping online like the inability to deliver on time.

3. As youths prefer shopping online to traditional shopping, firms should try and go online while maintaining the traditional shopping method due to those that adopt innovation very late.

4. Companies offering products and services online should focus on providing security on new websites to give online shoppers the confidence in shopping online without fear of losing money and other financial details.

5. Most youths in Nigeria have a fear of non-delivery while making an online purchase but prefer making payments on the delivery of the product by the marketing company. Therefore, online companies should 
provide collection centres in major cities in Nigeria to enable themto deliver to the right customer and get paid.

\section{REFERENCES}

[1] Abiodun, E. (2015), Nigeria's E-Commerce Sector to Grow to \#2.5 trillion by 2018. This day live June 10, Retrieved from www.thursdaylive.com/articles on August 20, 2015.

[2] Adinibigbe, N. (2015), Nigeria is Africa's Leading E-Commerce Market. Ventures Africa, Feb. 20. www.ventures Africa.com

[3] Aginam, E (2014), Study Shows High Growth of E-Commerce in Nigeria Vanguard, August 6

[4] Anthony, B. (2015) Growth of E-Commerce in Nigeria. Retrieved from www.Mobilemedia.Info.tech.wordpress.com

[5] Bellman, S., Lohse, G.L, and H.R Johnson (1999). Predictors of Online Buying Behaviour Communications of the ACM, 4 (12), Pp: 3238.

[6] Chou, P. (2015), Online Marketing Retrieved from www.wisdomportal.com/books/onlinemarketing.html.

[7] Devi, S.C, and Anitha, S. (2013) "E-Marketing Challenges and Opportunities". International Journal of Science Research and management. Special Issue on E-Marketing Road Ahead of India. Pp 96-105.

[8] Donthn N., and Garcia, A. (1999).The Internet Shopper Journal of Advertising Research, 39(3), Pp 52-58.

[9] Janssen, C. (2015), Online Marketing. Retrieved from www.technopedia.com/definition/21363/onlinemarketing.

[10] Javadi, M. H.M., Dolatabadi, H.R., Nourbakhish, M., Poursaeedi, A., and. Asadoolam, A.R. (2012), “An Analysis of Factors Affecting on Online Shopping Behaviour of Consumers”. International Journal of Marketing Studies Vol. 4, No.3, Pp. 80 - 92.

[11] Li, N., and Zhary, P. (2002), Consumer Online Shopping Attitudes and Behaviour: An Assessment of Research. Information Systems Proceedings of Eight Americas Conference.

[12] Liary, T., and Lai, H. (2000), Electronic Store Design and Consumer Choice: An Empirical Study Systems Sciences Proceedings of 33 ${ }^{\text {rd }}$ International Conferences in Hawail

[13] Moris, (2013), Online. www.sj.com/news/articles.

[14] Sharma, R., Melita, K., and Sharma, S. (2014), "Understanding Online Shopping Behaviour of India Shoppers" International Journal of Management and Business Studies. Vol. 4 (3) July-Sept.

[15] Sinha, J. (2010), Factors Affecting Online Shopping Behaviour of India Consumers: Doctoral Dissertation, Univeristy of South Carlina, USA.

[16] Swaminathan, V. Lepkowska-Whiter, E. and Roa, B.P. (1999), "Browsers In Buyers In Cyberspace? An Investigation of Factors Influencing Electronic Exchange". Journal of Computer-Mediated Communication. Vol. 5 (2) Pp 20-30.

[17] Ward, S. (2015), Online Marketing. www.sbinfocanada.abound.com/od/marketing/g/onlinemarketing.htm.

[18] Yulihasi, M.D. Islam, A. and Dand, K.A. (2011), "Factors That Influence Customers' Buying Intention on Shopping Online', International Journal of Marketing Studies. Vol.3, No 1. Pp 128-139. 